$12-1991$

\title{
Benjamin Franklin on population: From policy to theory
}

\author{
Dennis Hodgson \\ Fairfield University, hodgson@fairfield.edu
}

Follow this and additional works at: https://digitalcommons.fairfield.edu/sociologyandanthropology-

facultypubs

Archived with permission from the copyright holder.

Copyright 1991 Wiley and Population Council.

Link to the journal homepage: (http://wileyonlinelibrary.com/journal/padr)

\section{Peer Reviewed}

\section{Repository Citation}

Hodgson, Dennis, "Benjamin Franklin on population: From policy to theory" (1991). Sociology \& Anthropology Faculty Publications. 33.

https://digitalcommons.fairfield.edu/sociologyandanthropology-facultypubs/33

\section{Published Citation}

Hodgson, Dennis. "Benjamin Franklin on population: From policy to theory." Population and Development Review 17, no. 4 (December 1991): 639-661.

This item has been accepted for inclusion in DigitalCommons@Fairfield by an authorized administrator of DigitalCommons@Fairfield. It is brought to you by DigitalCommons@Fairfield with permission from the rightsholder(s) and is protected by copyright and/or related rights. You are free to use this item in any way that is permitted by the copyright and related rights legislation that applies to your use. For other uses, you need to obtain permission from the rights-holder(s) directly, unless additional rights are indicated by a Creative Commons license in the record and/or on the work itself. For more information, please contact digitalcommons@fairfield.edu. 


\title{
Benjamin Franklin on Population: From Policy to Theory
}

\author{
DenNis Hodgson
}

BENJAMIN FRANKLIN WROTE HIS Observations Concerning the Increase of Mankind in 1751. It was published, anonymously, in 1755 and was reissued ten times during the next 15 years, both in America and abroad. ${ }^{1}$ This work was one of those rare instances in which ideas traveled eastward across the Atlantic. Adam Smith, David Hume, Lord Kames, Richard Price, Turgot, and, of course, Malthus were influenced by it, ${ }^{2}$ as was nearly every American writing on population during the latter half of the eighteenth century. ${ }^{3}$ It is remembered today as an influential precursor of Malthus's Essay on Population.

There is a riddle in Franklin's treatment of population. In his Observations he elaborated an essentially pessimistic theory about the role population dynamics plays in human affairs. Observing that reproductive capacity was much greater than that needed for replacement, he asserted that the availability of subsistence ultimately determined population size and growth, and he identified high population density as being responsible for many of Europe's ills. Yet he was unfailingly enthusiastic about colonial population expansion, advocating early marriage, large families, and rapid population growth, and expressing no ambivalence about colonial growth, no worry that a population doubling every 25 years might simply be laying the groundwork for future suffering. The unreconciled strands of "optimism" and "pessimism" running through his treatment of population (Himes, 1937: 389390) have long beguiled chroniclers of population thought.

Some deal with this disjunction by arguing for the centrality of one strand. Hutchinson, like most demographers, treats Franklin as essentially a pessimist since in the latter's theory the availability of subsistence determines population dynamics. ${ }^{4}$ Aldridge (1965: 86), in contrast, finds Franklin's 
"philoprogenitiveness," his belief that "procreating numerous offspring was a good in itself," the key to understanding his thought; ${ }^{5}$ Conner (1965: 6987), too, takes this stand. ${ }^{6}$ Himes (1937: 388-391), Cassedy (1969: 157170), Detweiler (1975), and Gibson (1989: 6-17) present both strands of Franklin's thought and attempt to integrate them by pointing out the different economic and demographic situations of the Old and New Worlds in Franklin's time. Population growth in a sparsely settled land was an immediate need and a source of strength, while in the old World it was associated with misery. However, no commentator offers an explanation for Franklin's ignoring the long-term economic and social implications of New World population expansion. Silence on this point is, perhaps, wise. Franklin's proclivity to reflect on the future and his mathematical sophistication make it difficult to attribute this lapse to inattention or shortsightedness. That 1 million doubling each 25 years becomes over 4 billion in a scant 300 years was undoubtedly clear to Franklin. Questions still surround Franklin's actual sentiments on population's role in human affairs.

Uncovering these sentiments is no simple matter. Franklin's public pronouncements on population cannot be assumed to directly reflect his actual position. Normally policy recommendations flow from theoretical understanding, but with Franklin this was not the case. He elaborated his theory in a pre-independence environment in which the colonies' economic and demographic interests were becoming increasingly distinct from those of the mother country. He had few means, other than his intellect and his pen, of influencing actual colonial policymakers: British governors, Parliament, and colonial officials. Since this audience did not share his allegiances, he often addressed it anonymously, sometimes posing as an Englishman. Since it could not be swayed by overt advocacy of policies designed to further colonial interests, he often sought to influence it by persuasive theoretical argument. ${ }^{7}$ Accurately interpreting his population writings requires situating them in such a historical context.

\section{Franklin's pronatalist convictions}

Franklin's theoretical treatises on population were largely byproducts of his career as politician and public official, a career that began with his election to the Pennsylvania Assembly in 1751. But earlier, while printer and journalist, he had often touched on demographic themes, most noticeably by offering vigorous defenses of marriage and parenthood. These "natural" institutions Franklin considered the cornerstones of human happiness. In 1735, posing as a thrice-married older man, Franklin vigorously rebutted (p. 23) a doggerel appearing in The Pennsylvania Gazette that attacked marriage: "A Man does not act contrary to his Interest by Marrying; for I and Thousands more know very well that we could never thrive till we were 
married; and have done well ever since." Later he observed (1744: 396): "He that has not got a Wife, is not yet a compleat Man."

No prude, either on paper or in life, Franklin distinguished between sex and marriage and while favoring both, even when uncoupled, always advocated marriage. When informing a young man on the benefits of an older as opposed to a younger mistress, Franklin first recommended marriage (1745: 30) since it "is the most natural State of Man, and therefore the State in which you are most likely to find solid Happiness." A single man, he contended, is an "incomplete Animal" who "resembles the odd Half of a Pair of Scissars." More than 20 years later he congratulated (1768: 183184) a young man recently married for escaping an "unnatural State" and being "now more in the way of becoming a useful Citizen." Early marriages followed Nature's plan- "when Nature has render'd our Bodies fit for it, the Presumption is in Nature's Favour, that she has not judg'd amiss in making us desire it": they also "stand the best Chance for Happiness."

His defense of parenthood was along similar lines: not having children is unnatural and, ultimately, regrettable. He asked (1735: 22): "For what old Batchelor can die without Regret and Remorse, when he reflects upon his Deathbed, that the inestimable Blessing of Life and Being has been communicated by Father to Son through all Generations from Adam down to him, but in him it stops and is extinguished." He presented (1735: 23) a powerful analogy between "planting" and parenting and argued that what some call the "Bondage" and "Cares" of raising a family are actually akin to the "delight" and "pleasure" that a planter has in tilling his "fertile Garden" and "raising as many beautiful and useful Plants from it as he can." Much later he extolled (1768: 184) early marriages since they tend to be "blest with more Children."

Procreation was such a praiseworthy act that Franklin defended unwed mothers. He fabricated a courtroom speech in which a never-married mother, supposedly being prosecuted in Connecticut for the fifth time for "having a Bastard Child," argued before the Court (1747: 125): "What must poor young Women do, whom Custom have forbid to solicit the Men, and who cannot force themselves upon Husbands, when the Laws take no Care to provide them any; and yet severely punish them if they do their Duty without them; the Duty of the first and great Command of Nature, and of Nature's God, Encrease and Multiply. "8 Polly Baker, the fictitious mother, made it clear that bachelors, who "have never sincerely and honourably courted a Woman in their Lives," were more guilty than she since they "leave unproduced (which is little better than Murder) Hundreds of their Posterity to the Thousandth Generation."

The constancy of Franklin's "naturalistic" endorsements of marriage and large families suggests that these were his unvarnished views. One question, though, can be raised about the source of his pronatalism. Franklin 
believed that early marriage and large families were advantageous to colonial interests. In 1747 he had Polly Baker (p. 124) plead before the Connecticut judge: "Can it be a Crime (in the Nature of Things I mean) to add to the Number of the King's Subjects, in a new Country that really wants People? I own it, I should think it a Praise-worthy, rather than a punishable Action." The fortuitous convergence of individual inclination and social benefit in Franklin's thought does little to clarify his priorities. Would early marriage and large families still be "natural" and "good" if the "Country" had no need for more people? Franklin (1768: 184), speaking of marriage, did recognize that "prudence" and "nature" could sometimes be in conflict: "Particular Circumstances of particular Persons may possibly sometimes make it prudent to delay entering into that State." Some doubt remains as to whether Franklin's pronatalism was more a reflection of his view of human nature or of his assessment of colonial needs.

\section{Franklin's treatises on population}

Such problems of interpretation multiply when dealing with Franklin's more theoretical works on population. Once his career as statesman began in earnest in the 1750s, he repeatedly advanced treatises on population as a means of influencing colonial policy debates-the most notable examples being his Observations (1751), A Plan for Settling Two Western Colonies (1754), and The Canada Pamphlet (1760). He was familiar with European thinking on the topic (Aldridge, 1949: 26-28) and followed the form common to works of political economy, establishing premises and logically deducing conclusions. If one assesses these treatises as pure works of political economy, however, one gains little insight about their genesis or originality. This comes only with recognizing Franklin's policy intent and examining these treatises in conjunction with the policy debates they were written to influence.

Britain had a particular set of demographic concerns about its North American colonies that came to the surface at mid-century. The colonies were useful primarily as markets for British manufactures. The growing demand for British goods that flowed from colonial population increase was appreciated, yet not without misgivings. Emigration to America was thought to be reducing Britain's strength while enhancing that of the colonies. Some feared that as the colonies' population reached significant levels, moves toward independence would be more likely and more difficult to thwart. Issues of control, trade, and expansion were central British concerns. The supervision and defense of the colonies entailed significant costs. Opening up new areas of settlement, especially those away from the seacoast and on the other side of the Alleghenies, was of uncertain commercial benefit. The likelihood of sizable trade diminished while the costs of control increased. Conflict with the French further complicated British policy formation. French 
dominance of the Mississippi and the St. Lawrence regions encircled the colonies and placed the frontier in French hands. With respect to colonial expansion, commercial concerns and imperial concerns often pulled British policymakers in different directions (Stourzh, 1969: 34-43).

Franklin, like nearly every colonist, had a much clearer population agenda. He considered the expansion of the colonies, both demographically and territorially, to be essential for continued prosperity. He was an important participant in plans to form two new colonies in the Ohio region, ${ }^{9}$ and dreamed of filling the continent. He also exemplified colonial displeasure with British officialdom's presumption that colonial policy should be formed to serve the mother country's interests. When a British Parliament, with no colonial representation, passed laws that hurt colonial interests, Franklin invariably objected. Although at mid-century no advocate of independence, Franklin did attempt to form a colonial union whose single voice would better be heard in policy debates. His vision was of a British Empire in which all citizens, whether resident of colony or mother country, were of equal standing. It found little support in Britain. From 1757 to 1775 he spent nearly all his time in London, serving as colonial agent for the Pennsylvania Assembly, and later for Georgia, New Jersey, and Massachusetts. ${ }^{10}$ He was (Wright, 1986: 355) "the closest there could be to an American ambassador."

Much of Franklin's public writing during this period, including his population theorizing, focused on convincing British officials that pursuing policies detrimental to the interests of the colonies was unjust and unwise. He employed all his rhetorical skills in the task: irony, humor, sarcasm, and logic. When Britain forbade colonial assemblies from passing "any Law preventing or discouraging the Importation of Convicts from Great Britain," Franklin (1751b: 131-132) responded with irony: "Such a tender parental Concern in our Mother Country for the Welfare of her Children, calls aloud for the highest Returns of Gratitude and Duty." He suggested an annual shipment of some thousands of "these venomous Reptiles we call RATTLESNAKES" to London and their distribution in "the Gardens of the Prime Ministers, the Lords of Trade and Members of Parliament" as the appropriate thanks.

His three letters to Governor William Shirley in 1754 constitute a classic critique of the colonial system from the perspective of the colonized. He labeled (1754a: 450-451) the restraint on colonial trade an indirect tax and questioned its legitimacy: "Could the Goodwin Sands be laid dry by banks, and land equal to a large country thereby gain'd to England, and presently filled with English Inhabitants, would it be right to deprive such Inhabitants of the common privileges enjoyed by other Englishmen, the right of vending their produce in the same ports, or of making their own shoes, because a merchant, or a shoemaker, living on the old land, might fancy it more for his advantage to trade or make shoes for them? . . . [W] hat imports it to 
the general state, whether a merchant, a smith, or a hatter, grow rich in Old or New England?" He noted with concern (1754a: 444-445) that "Governors often come to the Colonies meerly to make Fortunes," and argued that giving them the power to levy taxes would lead not only to abuses but also to resentment since "compelling the Colonies to pay Money without their Consent would be rather like raising Contributions in an Enemy's Country, than taxing of Englishmen for their own publick Benefit."

Franklin's population theorizing began (1750: 440-441) with some musings in Poor Richard Improved, 1750: "What the natural Increase of Mankind is, is a curious Question. . . . I believe People increase faster by Generation in these Colonies, where all can have full Employ, and there is Room and Business for Millions yet unborn. For in old settled Countries, as England for Instance, as soon as the Number of People is as great as can be supported by all the Tillage, Manufactures, Trade and Offices of the Country, the Overplus must quit the Country, or they will perish by Poverty, Diseases, and want of Necessaries." He estimated (p. 440) the doubling time of the colonial population at 30 years. A year later, in a letter to James Parker (175la: 121), he added a migration component: "I question indeed, whether there be a Man the less in Britain for the Establishment of the Colonies. An Island can support but a certain Number of People: When all Employments are full, Multitudes refrain Marriage, 'till they can see how to maintain a Family.' Basic components of his population theory were appearing, awaiting only a stimulus to pull them together.

Parliament's passage in 1750 of the Iron Act prohibiting the construction of new forges and silting mills in the colonies stirred him to write the Observations Concerning the Increase of Mankind the following year (Van Doren, 1938: 216). His purpose was clear. He later spoke (1755b: 276) of the Observations as a "little Paper, tending to show that such Jealousies with Regard to Manufactures were ill-founded" and noted (1755a: 217) that in the winter of 1754 "Governor Shirley persuaded me it might be of some Use to permit the Printing of my Paper on the Peopling of Countries, \&c. at the End of a Pamphlet then preparing for the Press per Dr. Clarke, on the Importance of the Colonies to Great Britain." Wright (1986: 81) considers the Observations an appraisal of "the relationship between colony and mother country," and Cassedy (1969: 161) observes that it "was not intended as a scholarly demographic study." In some ways treating it as an unbiased attempt to understand demographic trends leads to an unfairly low assessment of Franklin's scientific prowess. Yet treating it as simple propaganda ignores Franklin's use of logic and deductive reasoning, the social scientific method of his day, and belittles the quality of its demographic insights. Distinguishing scientific from polemical argumentation is not easy, but understanding Franklin's population thought requires that we make such an attempt.

Although demographers remember the Observations for its bleak theory concerning the inherently excessive nature of reproduction and for instances 
of accurate demographic analysis-specifying the doubling time of America's population at 25 years, noticing that luxury and city-living result in lower fertility-only by recalling Franklin's policy mission can its odd twists and turns be explained. Franklin adopted the stance of an expert advisor who is outlining the laws governing the increase of mankind so that wise policy might be implemented. " This advisor presumed that the power and strength of the state were of supreme importance and he adopted mercantilistic assumptions: a nation's strength is determined by a positive balance of trade, especially one based on exporting manufactures; the growth of one's own population enhances strength, while that of other nations detracts from it; and so on. Although Franklin elsewhere wrote on population as a "friend to the poor" (1773), in the Observations he made no pretense of outlining a policy aimed at improving the lot of the masses. His treatment of "luxury" and its negative effect on fertility (1751c: 232) made this clear: "The greater the common fashionable Expence of any Rank of People, the more cautious they are of Marriage. Therefore Luxury should never be suffer'd to become common."

Franklin's treatment of population increase concentrated on marriage (p. 227): "For People increase in Proportion to the Number of Marriages, and that is greater in Proportion to the Ease and Convenience of supporting a Family. When Families can be easily supported, more Persons marry, and earlier in Life." He assumed that individuals "naturally" will choose early marriage and have large families whenever conditions permit, and pointed (p. 228) to America's 20-year age-at-marriage and its eight "Births to a Marriage" to substantiate this proposition.

His was a sophisticated vision of population dynamics, one that recognized the independent influence exerted by economic, political, and social institutions. He related the relative sparsity of America's Indian population to its reliance on hunting and developed a typology of economies with an increasing man/land ratio: hunting, husbandry, gardening, and manufacturing economies. Politics influenced population size by affecting employment opportunities, and large and dense populations were evidence of adept policy. Polities that were conquered, that lost territory or food sources or trade, that permitted slavery or the importation of foreign luxuries, or that disregarded private property rights would experience a decline in marriages and population. Socially, living in environments "fully settled" and being accustomed to luxury increased the costs associated with starting a family and so inhibited marriage and population growth. Lives of idleness (allowed by owning slaves or much property) decreased fertility by "enfeebling" individuals and making their children (p. 231) "proud, disgusted with Labour" and "rendered unfit to get a Living by Industry."

Franklin concluded the Observations by giving his population theory a biological underpinning, one that has led many to view him as a precursor of Malthus. He presented (p. 233) man's tendency to marry early and have 
large families as but one instance of a general natural law: "There is in short, no Bound to the prolific Nature of Plants or Animals, but what is made by their crowding and interfering with each others Means of Subsistence." Every species, human included, reproduces in numbers greater than that needed for simple replacement, and will expand its domain until held in check by some outside force.

\section{Franklin's policy deductions}

The policy implications that Franklin derived from this theory of population were numerous and remarkably consistent with his assessment of colonial interests. Even his biological conclusion had policy import, providing an entrée for chauvinistic advice to the prince (p. 233): "Was the Face of the Earth . . . empty of other Inhabitants, it might in a few Ages be replenish'd from one Nation only; as, for Instance, with Englishmen." His final two paragraphs made clear his intent. North America was a largely "empty" continent that should be filled with Englishmen. He asked: why should "Palatine Boors be suffered to swarm into our Settlements . . . why increase the Sons of Africa, by Planting them in America, where we have so fair an Opportunity, by excluding all Blacks and Tawneys, of increasing the lovely White and Red?" He admitted that this preference for an English complexion was based on prejudice, but he declared (p. 234) "such Kind of Partiality" to be "natural."

Franklin's immediate goal was to influence British policy governing colonial expansion, migration, manufacturing, and trade. He found that his theory sustained each of his policy positions. Europeans brought to the New World an agricultural technology that expanded the carrying capacity of a continent inhabited by hunters: under husbandry, "vacancies" appeared in areas that formerly were fully settled. Expansion was both natural and inevitable since the young now had access to land that would allow them to marry early and support large families. Attempts to limit expansion were bound to fail. British fears that colonial population increase came at the expense of its Old World inhabitants were unfounded. Franklin, contradicting his earlier analysis, ${ }^{12}$ asserted (p. 233) that the one million "English Souls in North-America" were more the result of "natural Generation" than of migration since only 80,000 had ever sailed from Britain. He further claimed that even this 80,000 had not diminished British numbers. By depicting (p. 228) Old World countries as fully populated, with no "vacancies" left, he could claim that emigration did not lead to a reduction in their population but simply permitted those remaining at home to marry earlier and have more surviving children. Franklin even hinted (p. 233) that emigration to the colonies might actually have increased the British population "on Account of the Employment the Colonies afford to Manufactures at Home." In any case, there was no need for legislation to curb emigration. 
Manufacturing and trade policies were deduced in more circuitous ways. Franklin (p. 227) began with a mercantilist social theory that related population growth to changes in class structure and in economic institutions. The effective governing of a limited area results in population increase, and once "all Lands being occupied and improved to the Heighth: those who cannot get Land, must Labour for others that have it; when Labourers are plenty, their Wages will be low." Manufacturing requires a substantial pool of low-wage workers and therefore only develops in fully settled countries. This theory predicted that colonial manufacturers would be unable to compete with their British counterparts for "many Ages," until "the Territory of North-America" was fully settled. With hired laborers easily able to acquire land of their own, colonial wages had to be high. As long as land remained abundant, the economy would be agricultural and large numbers of poor would never develop. Franklin rebutted (pp. 229-230) the objection "that by the Labour of Slaves, America may possibly vie in Cheapness of Manufactures with Britain" by meticulously toting up the various costs of a slave (price, interest, insurance, sustenance, overseeing, etc.) and documenting that "the Labour of Slaves can never be so cheap here as the Labour of working Men is in Britain." Slavery existed only because it was so difficult to keep free labor from leaving and "setting up for themselves."

After deducing that British restriction of colonial manufacturing was unnecessary, Franklin argued that it would prove harmful as well. He predicted (p. 229) so rapid a colonial population increase that demand for manufactured goods would "increase in a short Time even beyond her [Britain's] Power of supplying." High demand would increase the price of British goods, "drive her Merchants out of Foreign Markets," harm the colonial economy, and allow Britain's rivals to "grow more populous and more powerful." He recommended that Britain "not too much restrain Manufactures in her Colonies." In this scenario Franklin's advocacy might have overwhelmed his logic. Exactly how high demand led to loss of markets was unclear, and seemed to require an odd interaction of supply, demand, and price. The mercantilist perspective that Franklin had assumed for the essay was also undercut. Although describing (p. 229) the colonies as "a glorious Market wholly in the Power of Britain, in which Foreigners cannot interfere," he implied that exploiting this market would be harmful to Britain. Nor was it clear how the colonies might benefit from the removal of restrictions. With land still abundant, from whence would the low-wage workers come who would allow colonial manufacturers to compete with their British rivals? Furthermore, by placing all the costs of restricting colonial manufacturing in the future, he removed any urgency from the current policy debate: present benefits were countered only with hypothetical future costs. Ironically, Franklin presented the least-convincing arguments about the very policy debate that provoked him to write the essay. 
The notion that humans are so prolific that "crowding and interfering with each others Means of Subsistence" determines their number is such a general proposition that a dexterous thinker could deduce from it nearly any policy recommendation. One need only recall the very different recommendations that Malthus drew from the same premise. In the Observations Franklin evidenced a remarkable facility with ideas, harmonizing his deductions with colonial interests. However, he avoided problems of consistency only by treating each policy issue as a discrete topic. Many incongruities appear when his deductions are viewed as a totality. For instance, consider his treatments of emigration and manufacturing. If manufacturing requires a large pool of low-wage workers, should not easy access to abundant land in the colonies drain these pools, and a substantial percentage of the British population, until density and living conditions equalize in both territories? By choosing the high-wage work and farming of the colonies over low-wage factory work, Britons as well as Americans could marry earlier and lead better lives. Those whom the first emigrants left behind should emigrate themselves, not simply marry slightly younger and have more children. In different contexts, Franklin occasionally even arrived at contradictory assessments of the same phenomenon. Consider, for instance, Franklin's argument that colonial population growth would increase demand for British manufactured goods. When examining the expansion of the colonial population, Franklin contended that this increased demand was beneficial to Britain: more demand results in more jobs and people in Britain. When examining the consequences of restricting colonial manufacturing, he contended that this increased demand was harmful to Britain: more demand results in higher prices and loss of markets. Such incongruities illustrate that Franklin's policy recommendations were not the products of a simple process of deduction.

\section{Franklin: The pragmatist}

Franklin continued to use demographic arguments to advance colonial interests and to assuage British fears. Encouraged by the positive reception given the Observations, he persistently cited that work and participated in its reissue. Yet he also showed a surprising willingness to alter elements of this pivotal theory, sometimes in significant ways, to meet the exigencies of new policy debates. Examining these later works sheds light on Franklin's pragmatic use of population theory.

Even before the Observations was finally published in 1755, Franklin presented an additional view of the demography of colonial expansion. In the fall of 1754, just prior to the outbreak of the French and Indian War, he published $A$ Plan for Settling Two Western Colonies. It promoted the establishment of English colonies in "the great country back of the Apalachian mountains, on both sides of the Ohio" by skillfully interweaving (1754b: 
457-458) hostility to France with population theory: "1. Our people, being confined to the country between the sea and the mountains, cannot much more increase in number; people increasing in proportion to their room and means of subsistence. 2. The French will increase much more, by that acquired room and plenty of subsistence, and become a great people behind us. 3. Many of our debtors, and loose English people, our German servants, and slaves, will probably desert to them; and increase their numbers and strength, to the lessening and weakening of ours. . . . 5. They will both in time of peace and war (as they have always done against New England) set the Indians on to harass our frontiers, kill and scalp our people, and drive in the advanced settlers; and so, in preventing our obtaining more subsistence by cultivating of new lands, they discourage our marriages, and keep our people from increasing; thus (if the expression may be allowed) killing thousands of our children before they are born."

Only minor modifications of Franklin's population thought appear in this work. Depicting a foreign adversary as seeking to fill America's empty spaces allowed him to argue that colonial expansion was an urgent necessity and not an inevitability. He adroitly superseded the conflict of interest between colonies and mother country with a unity of purpose. New colonies would lead to (p. 459) "the great increase of Englishmen, English trade, and English power" and would thwart the French, things desired by Englishmen everywhere. He also altered the time frame used in the Observations. The colonies had rather suddenly become "full," a quality they previously lacked.

After the fall of Quebec in 1759 it became obvious that France would be defeated. With the removal of the French threat, colonial and British policy differences over expansion soon reemerged. They were sharply exposed in the debate that broke out in 1760 over which of France's territories Britain should seek to keep permanently: Canada, whose expansive area promised to support a substantial market for British manufactures in the future, or Guadeloupe, a currently productive sugar island. ${ }^{13}$ Franklin, in London as Pennsylvania's colonial agent, contributed one of the more than 65 pamphlets that appeared on this topic: The Canada Pamphlet (1760). Writing anonymously and posing as an Englishman, he specifically sought to counter the Remarks on the Letter Address'd to Two Great Men. William Burke's pamphlet advocating the retention of Guadeloupe and the returning of Canada. Burke had incensed Franklin by contending that British interests would be served by a French Canada since it would help "check" the colonies and make any move toward independence less likely. Franklin attacked (pp. 93-95) with rhetorical fervor: "We have already seen in what manner the French and their Indians check the growth of our colonies. 'Tis a modest word, this, check, for massacring men, women and children." In good Swiftian fashion he offered a more humane solution: "If it be, after all, thought necessary to check the growth of our colonies, give me leave to propose a 
method less cruel. . . . Let an act of parliament, [then,] be made, enjoining the colony midwives to stifle in the birth every third or fourth child."

The bulk of the essay was a reasoned explanation, largely demographic in content, of why Canada should be added to the British dominion. Several significant modifications of his original population theory were presented. In the Observations he had assessed the danger of colonial competition in manufacturing as "too remote to require the Attention of Great-Britain" (1751c: 229). In 1760 the danger had become imminent. He depicted (1760: 73) the colonies as "soon" approaching the limits of their capacity as agricultural lands, and warned that unless territories such as Canada were annexed, British manufacturers faced certain colonial competition, and "all the penal and prohibitory laws that ever were thought on, will not be sufficient to prevent manufactures in a country whose inhabitants surpass the number that can subsist by the husbandry of it." More startlingly, he removed the biological underpinnings of his population theory. He specifically contended (p. 79) that the British population was not "limited to their present number by any thing in nature, or by unchangeable circumstances." He differentiated (pp. 78-79) between the laws governing the growth of the "political body" and those governing the growth of biological organisms: "The human body and the political differ in this, that the first is limited by nature to a certain stature, which, when attain'd, it cannot, ordinarily, exceed; the other by better government and more prudent police, as well as by change of manners and other circumstances, often takes fresh starts of growth, after being long at a stand; and may add tenfold to the dimensions it had for ages been confined to."

Franklin was responding to concerns that he had helped to engender. Few in Britain had actually accepted Franklin's earlier assessment (175lc: 233) that rapid colonial population increase would produce a great "Accession of Power" for the "British Empire." His prediction (1751c: 233) that in only a century "the greatest Number of Englishmen will be on this Side the Water" had heightened British fears of colonial rebellion and played into the hands of those calling for a "check" to colonial growth. ${ }^{14}$ While neither his desires nor his theory would permit a less rapid colonial expansion, he could diminish such fears by vastly increasing Britain's own potential for population growth. In The Canada Pamphlet he removed all natural restraints to British population growth and indeed provided it with a colonial motor (p. 79): "In proportion therefore, as the demand increases for the manufactures of Britain, by the increase of people in her colonies, the numbers of her people at home will increase." No hint appeared that colonial population growth might lead to excessive demand for British manufactures, higher prices, and the ultimate decline of British industry and population. He even deleted the paragraph describing this scenario from the version of the Observations that he appended to The Canada Pamphlet. ${ }^{15}$ All Great Britain 
need now do (p. 79) to have "ten times its present number of people" was to allow colonial expansion.

His response to fears that acquiring additional "vacant" lands would result in "draining Britain of its inhabitants" was also new. He simply stated (p. 95) that it was "not now necessary that we should furnish" people to fill these lands since colonial natural increase was sufficient to ensure settlement. He ignored the issue of empty lands attracting emigrants from Great Britain. His new analysis made this avoidance wise. More clearly than before he related manufacturing and poverty (p. 73): "It is the multitude of poor without land in a country, and who must work for others at low wages or starve, that enables undertakers to carry on a manufacture." He also elaborated (p. 78), in a different context, a model of internal migration in which new settlements would "continually draw off the spare hands from the old." Explaining why impoverished British workers would not also be "drawn off" to these new settlements would be difficult.

Franklin was willing to forgo advocacy of unrestricted British emigration because he now had a more immediate policy goal: convincing Britain to retain Canada. By depicting the present colonies as fully settled agricultural areas, he added urgency to the need for new lands: the colonies were turning to manufacturing and British markets were endangered. Franklin's model of internal migration explained how acquiring new lands would forestall this. A frontier would "draw off" redundant workers, keep wages high (p. 78) and land prices low (p. 76), and preserve the agricultural character of all the colonies. No significant manufacturing would develop until the entire territory was "as fully peopled as England, that is for centuries to come." An endorsement of British emigration would raise the specter of British workers also flocking to the expanded frontier, hardly a vision likely to convince British policymakers to retain Canada.

Clearly Franklin was modifying his earlier theory to enhance its current political appeal. With colonial demand for manufactured goods directly producing people in Britain, population growth in America and Great Britain were now synchronized. With human populations following different laws of increase than those governing other species, the biologically implausible was possible (p. 79): "The growth of the children tends to encrease the growth of the mother, and so the difference and superiority is longer preserv'd." Severing the connection between a territory's ability to provide subsistence and its population dynamics also comforted those who lived on a relatively small island and sought global ascendancy. Their island was no longer "filled" in any ultimate sense, and significant expansion could be envisioned. Of course, the disparity between continent and island was too great for even Franklin to argue that numerical superiority would always remain with the mother country. But the vision of several centuries during which expansive agricultural colonies would aid the rise of British popula- 
tion, trade, and power was designed to appeal to the contemporary British policymaker.

Franklin's modified theory produced more palatable assessments of British demographic and political potential, but lost some of its theoretical coherence. Previously Franklin had linked a territory's carrying capacity with its population dynamics and its economic structure. Population grew until labor could no longer be productively employed on the land, after which it tapered off as redundant workers were forced to accept subsistence wages in manufacturing. Franklin now severed the link between carrying capacity and population size by identifying the demand for manufactured goods as the major determinant of British population dynamics. He left unchanged, however, the rest of his development model, continuing to assert that manufacturing was "founded in poverty" and those not employed on the land would be forced to accept low wages. But why manufacturing should continue to be associated with poverty was no longer clear. Should not the demand for labor alone, not the availability of agricultural work, determine wages? In an economy where many employers sought his labor, would a worker who refused one employer's low wages be forced to starve? With high demand for British goods, would not manufacturers have to compete for workers and offer higher wages? Did not Franklin imply as much when he contended that this increased demand would lead to increased numbers? What prevented manufacturing wages from surpassing agricultural wages? What prevented the depopulation of the British countryside? Many questions, enough to engage a generation of political economists, arose from Franklin's new population/development model. Franklin, with his attention fixed elsewhere, had little interest in such theoretical problems and did not acknowledge them.

During the 1760s, with open rebellion growing closer, Franklin increasingly contradicted his public contentions in his private letters. In a letter to Peter Collinson, an English colleague, Franklin simply dismissed (1764: 183) the notion that the colonies would remain dependent on British manufacturing: "as to our being always supply'd by you, 'tis a Folly to expect it. Only consider the Rate of our Increase, and tell me if you can increase your Wooll in that Proportion, and where, in your little Island you can feed the Sheep. Nature has put Bounds to your Abilities, tho' none to your Desires. Britain would, if she could, manufacture and trade for all the World; England for all Britain; London for all England; and every Londoner for all London. So selfish is the human Mind!" In a letter to his friend Lord Kames he unfolded (1767: 69-70) a vision of a soon-independent America: "But America, an immense Territory, favour'd by Nature with all Advantages of Climate, Soil, great navigable Rivers and Lakes, $8 \mathrm{c}$. must become a great Country, populous and mighty; and will in a less time than is generally conceiv'd be able to shake off any Shackles that may be impos'd on her, and perhaps 
place them on the Imposers. . . . [T] he Seeds of Liberty are universally sown there, and nothing can eradicate them." Franklin construed the economic and political significance of colonial population dynamics so differently in these private scenarios that little doubt can exist about his molding his public pronouncements to serve his policy agenda. He clearly believed that expansion of the colonies in territory and population increased their "might" and made independence more feasible. And if he thought that the colonies were soon to throw off their "Shackles" and free themselves from a "selfish" British trade policy, what must he have actually thought of the probability of a tenfold increase in the British population?

After 1770 Franklin openly adopted a different stance in his public writings on population: friend of the masses, not advisor to the Prince. Several articles advocating a Parliamentary ban on emigration to the colonies appeared in The Public Advertiser in 1773, apparently prompted by an increase in emigration from Scotland and Ireland that was causing hardship to large landowners. Franklin, in London serving a second stint as a colonial agent, posed as "A Friend to the Poor" and offered a rejoinder replete with references to individual rights that was based more on utilitarianism than on mercantilism. ${ }^{16}$ Individuals emigrated when the disparity between their life at home and life elsewhere was great, and the flow would not stop until that disparity lessened (1773: 525): “The different Degrees of Happiness of different Countries and Situations find or rather make their Level by the flowing of People from one to another, and where that Level is once found, the Removals cease." These flows were like "Ocean currents" under the influence of the "Law of Gravity" and were just as difficult to stop. He doubted (p. 526) Britain had the power to ban emigration, considering "the Multitude of Cruizers necessary effectually to make a Prison of the Island." Moreover, he thought it "unjust" to try. Individuals had (p. 527) a God-given right, "when their Subsistence fails in one Country, to migrate into another, where they can get a more comfortable Living." To infringe this right "merely to gratify a few avaricious Landlords" was a travesty: "Must Misery be made permanent, and suffered by many for the Emolument of One?" This treatment of emigration seemed penned by a different student of population than the Machiavelli who wrote the Observations.

Once open conflict broke out with Great Britain, Franklin overtly used demographic analysis as a weapon with which to fight for independence. He asked (1775: 218) a British friend to calculate "the time and expense necessary to kill us all," using statistics from the 1775 British military campaign: three million pounds expended to kill "150 Yankies," while "during the same time 60,000 children have been born in America." In "Comparison of Great Britain and America as to Credit, in 1777" Franklin gives (p. 512) a very different assessment of Great Britain's prospects than in The Canada Pamphlet: "Excepting a few Parks or Forests she has no new Land to cultivate, 
and cannot therefore extend her Improvements. Her Numbers of People too, instead of Increasing from increas'd Subsistence, are continually diminishing from growing Luxury and the greater Difficulty of maintaining Families, which of course discourages early Marriage. Thus she will have fewer People to assist in paying her Debt, and that diminish'd Number will be poorer."

Franklin's last extended treatment of population themes came in a 1782 pamphlet, "Information to those who would remove to America." His thoughts on population were interwoven with a treatment of America's social structure, and the connection between population and social theory was clearly evident. He told (1782: 604) new arrivals to America that they would find neither the poor nor the rich, but "a general happy Mediocrity." A large middle class, pragmatic values, high wages, and agriculture were American traits that Franklin linked with its low population density. A stratified society, a preoccupation with lineage, poverty, and manufacturing were Old World traits that he linked with high population density. America, he maintained (pp. 603-606), did not need those talented "in the Belles-Lettres" or "fine Arts," and would give no deference to "Persons of Family" and "Gentlemen, doing nothing of Value, but living idly on the Labour of others." Here honor went to the "Husbandman" and "the Mechanic" because "their Employments are useful." He advised (p. 612) poor immigrants to apprentice a son to an Artisan and use the money "to buy Land sufficient to establish themselves, and to subsist the rest of their Family by Agriculture." Franklin's own preferences were clear: America's values were his own. Until his death he sought to preserve these values by gaining expansive boundaries for the new country (Stourzh, 1969: 197-213).

\section{Understanding Franklin's population thought}

Franklin's population writings can be approached in a number of ways. ${ }^{17}$ His biography can be highlighted: the writings can be seen as a reflection of Franklin's values, the product of an individual with a certain background and set of experiences. Alternatively, ideas can be highlighted: the formation of Franklin's core population concepts can be traced, and their impact on the thought of others detailed. Finally, time and place can be highlighted: the writings can be related to a historical moment, seen as the reaction of a particular generation to the distinctive situation it encountered. Each approach offers insight into Franklin's thought, but each has Franklin appraising population's role in human affairs quite differently. Much of the "riddle" that surrounds Franklin's population work arises from its being approached from different paths.

When Franklin's population thought is viewed as a reflection of his personal values, he appears as an unabashed population optimist. From this perspective his ethnic and class preferences largely dictate his population 
positions. The English chauvinism found in the Observations becomes central to understanding his thought. It fueled his advocacy of Anglo-American demographic and territorial expansion and shaped his population theory. Although he might have argued in the Observations that certain natural laws made expansion inevitable, this piece was actually an effort to remove barriers to expansion and to see that Englishmen accomplished it. His chauvinism was deep-seated and long-lived (1751a: 120-121; 1753: 159-160; 1784: 263-264). His opposition to others' "planting" themselves in America was so great that his universal population pronouncements were often marred with nativist restrictions. He concluded (1773: 528) his utilitarian explanation of migration trends, in which individuals migrate in pursuit of "comfort," with an outburst against "German" immigration to an America that "Britons" have "a much better Right to." Similarly, class bias, not mercantilism, lay behind Franklin's desire that America remain agricultural. He preferred middle-class values and wanted America to be a middle-class society. ${ }^{18}$ He disliked highly stratified societies, and thought the extremely wealthy to be an enfeebled, parasitical class. Living in the mid-eighteenth century, he had a vision of middle-class society that was necessarily one in which the majority owned and worked their own lands.

This "value" approach contends that deeply cherished ethnic and class preferences, not theories, determined Franklin's population positions. Although elaborating something close to Malthusian theory, he did so in pursuit of ethnic and class goals and was never a "Malthusian." His persistent advocacy of early marriage and large families reflects a conviction that great benefits, individual and social, flow from population expansion under American conditions. His dream was of a prosperous and middle-class America, peopled largely by the English, that spanned a continent and confidently assumed a preeminent place among nations. Problems associated with future high levels of population density in America were largely theoretical and hence ephemeral to Franklin. He reflected little on them because theory, as such, was not a major source of his population convictions.

When the concepts in Franklin's thought are highlighted, his population work assumes a very different hue. A tendency for populations to expand until held in check by the lack of subsistence is central to Franklin's theory as elaborated in the Observations. He related population pressure to the Old World's miseries, and never claimed that America would be immune to it, only that its onset would be delayed (1782: 611): "Poor are to be found in Europe, but will not be found in America, till the Lands are all taken up and cultivated, and the Excess of People, who cannot get Land, want Employment." The validity of his policy deductions rested upon the validity of this central premise, and Franklin affirmed both. When commenting on the Observations in his private letters (1753: 160; 1755a: 217), he judged its "opinions" to be "right" and its "facts" to be "authentick." 
When others read the Observations they focused on the theory it expounded. Many were led to worry about the consequences of population growth, even in America. A whole strand of eighteenth-century Malthusianism developed in American thought (Spengler, 1935) that had Franklin's work at its base. Thomas Jefferson (1787a: 82-85) calculated the doubling time of Virginia's population at 27 years and projected a population of "between six and seven millions" in 95 years. He doubted whether the "land" could support so many, thought that the standard of living would decline after a size of 4.5 million had been reached, and argued for restricting the entry of "heterogenous foreigners." He contended (1787b: 442) that political corruption had a demographic etiology and foresaw its arrival in America: "I think our governments will remain virtuous . . . as long as there shall be vacant lands in any part of America. When they get piled upon one another in large cities, as in Europe, they will become corrupt as in Europe." James Madison was led to conclude (1786: 76) that "a certain degree of misery seems inseparable from a high degree of populousness." In a 1791 work that was "shot through with Franklin's influence" (Spengler, 1935: 701), Madison considered (p. 117) infanticide, starvation, disease, war, and emigration to be consequences of a naturally excessive reproduction. ${ }^{19}$

Ambivalence about American population growth was Franklin's legacy. The generation of founders all favored rapid population growth for the needed strength it gave to the new nation, but many accepted Franklin's social theory that high density was a cause of misery and inequality and worried about its long-term implications. ${ }^{20}$ That Franklin's work inspired such somber reflections on population, well before the appearance of Malthus's Essay, illustrates the potency of his ideas on population, as well as their inherent pessimism.

Was Franklin a Malthusian pessimist or a confident expansionist? Two approaches to his work have produced very different visions of Franklin's attitude toward population growth. Perhaps both are too stark. Although each approach captures a genuine element in Franklin's thought, each also disregards much that is significant. Franklin's population work was more than a reflection of his values. He was a master polemicist who could have simply presented persuasive propaganda favoring his policy positions. He chose to present theoretical treatments of population dynamics, ones that occasionally contained policy implications not supportive of his own positions. The significance of this choice should not be slighted. Conversely, seeing Franklin as a pessimistic theorist who traced human misery to excessive reproduction ignores one of the most notable features of Franklin's work: the malleability of theory in his hands. Sometimes natural laws determine population increase, sometimes decisions by the Prince lead to a tenfold increase. Sometimes emigration has no effect on a country's population size, sometimes outflows of migrants cannot be stopped until "comfort" 
is equalized throughout the world. Franklin was the author of all these theories, not just one.

Taking the third approach outlined above allows a single coherent Franklin to emerge. All the strands of his population thought form a whole cloth when viewed against the backdrop of his generation's situation. The aspirations and concerns of mid-eighteenth-century Americans were the warp and weft of Franklin's work. Americans wished to expand westward and exploit the fertile lands of a sparsely settled continent-and Franklin produced a population theory that argued such expansion was inevitable. Americans wished that suitable emigrants would come, increase their strength, and help tame a continent-and Franklin produced a population theory that argued such emigration was unstoppable. Americans felt oppressed by restrictions placed on their industry and commerce-and Franklin produced a population theory that argued such restrictions were unnecessary and harmful. Although others were making key decisions that affected American lives, Franklin always endeavored to align those decisions with American wants. In his hand theory assumed different forms in different places, but was always shaped to aid the attainment of his generation's goals. Policy did not flow from theory, theory flowed from policy. Logical consistency was not emphasized, political utility was.

Although periodically assuming that population dynamics were determined by the availability of subsistence, Franklin was not an inherently pessimistic theorist. In the context in which he wrote, his theory was optimistic: the aspirations of Americans were in harmony with the laws of nature and the principles of good government. He was also, however, a serious student of his time. His observations of the relationship between demographic conditions and social institutions affected his thinking. He believed that high population density intensified inequities, multiplied the poor, and promoted manufacturing. It is doubtful, though, whether he considered these relationships to be immutable. ${ }^{21}$ In both deed and word, he affirmed his belief in a people's power to exert significant control over its destiny. He thought Americans were blessed to have a sparsely settled continent before them. For the pragmatic Franklin, their prospects were neither assured nor bound to fail. They were simply promising.

Franklin was an English chauvinist and a precursor of Malthus, but, above all, he was a spokesman for his generation. His writings make clear that the setting in which demographic inquiry takes place greatly influences its form and content. Contemporary demographers might be troubled by Franklin's tendency to mold theory to the needs of policy, but they would be wise not to dismiss him as an apostate. Each generation has its aspirations and concerns, its policy goals. Its students of population, infused with such aspirations and concerns, have the task of reconciling them with prevailing demographic conditions. Demographic theory, therefore, is routinely con- 
structed under the influence, to some degree, of a preexisting policy orientation. This is why one can so often "read" a generation's goals in the legacy of population theory that it leaves behind. Franklin's theory is clearly open to such an interpretation. Will the theory being constructed by contemporary demographers be free of all such influence of time and place? Should it be?

\section{Notes}

The Papers of Benjamin Franklin, Vols. 1 to 28 (New Haven: Yale University Press, since 1959) is the source used for all Franklin quotes up through February of 1779 . This work will be cited as Papers in the following notes and references.

1 For a brief publication history of the $O b$ servations see Papers 4: 226. It was still being reprinted in eighteenth-century journals as late as 1789 (American Museum 5 [February]: 109-112) and has recently appeared in Population and Development Review 11, no. 1 (March 1985): 107-112. Most reissues have deleted its chauvinistic conclusion: the paragraph opposing German immigration to Pennsylvania and the paragraph objecting to the importation of blacks from Africa.

2 For Franklin's influence on European thinkers see Wetzel (1895: 27-29), Carey (1928: 57-60), Spengler (1935: fnt. 23, pp. 698-699), Himes (1937: 388-398), and Zirkle (1957: 59-60). Cassedy (1969: 154, 158, 170-172, 183-184) provides the greatest detail on Franklin's interaction with English, French, and German students of population. Aldridge (1949: 25, 30-32) downplays the influence of Franklin on Malthus, who made no mention of Franklin in the first edition of his Essay.

3 Cassedy notes (1969: 172) that "Franklin's views on population became well known" throughout the colonies, emphasizing his influence on Ezra Stiles and mentioning also Thomas Jefferson, Edward Wigglesworth, William Barton, and Benjamin Rush. Spengler notes (1935: 699) his profound influence on Mathew Carey. Certain of James Madison's writings so closely mirror Franklin's works that he, too, must be counted among those influenced by Franklin (see note 19). Generally, Franklin was among the best known of eighteenth-century figures (Wright, 1986: 261-262, 269-270). John Adams asserted $(1811: 660)$ that "Franklin's fame was universal. His name was familiar to government and people, to kings, courtiers, nobility, clergy, and philosophers, as well as plebcians, to such a degree that there was scarcely a peasant or a citizen, a valet de chambre, coachman or footman, a lady's chambermaid or a scullion in a kitchen, who was not familiar with it. . . "

4 Hutchinson discusses (1967: 113-117. 134, 141) Franklin's thought in the context of treating "the development of pessimistic doctrine before Malthus" and specifically links the ideas expressed in the Observations to those found in other eighteenth-century works. Interestingly, although dividing eighteenth-century population thought into "pessimistic" and "optimistic" schools, Hutchinson makes no reference to Franklin's advocacy of colonial population growth.

5 Aldridge extensively treats (1949: 35 ; 1965: 83-90, 106-107) Franklin's pronatalism. He acknowledges (1949: 35) Franklin's pessimistic side, but does not attempt to explain it: "Franklin, despite his recognition that life depends upon subsistence, consistently reflects the general eighteenth-century view that population increase is a national blessing."

6 Conner simply takes up the "optimistic" strand in Franklin's thought, and only in a footnote (1965: 237) does he refer to Franklin's linking population growth to the means of subsistence: "He realized in theory the possibility of population outrunning food supply, but the American case was apparently to receive Divine exemption.' 
7 Spengler observed (1935: 698) that "Franklin used his population doctrines in the manner of a pamphleteering propagandist."

8 Franklin did not confess his authorship of this speech until 1788. It was reproduced many times, both in America and Europe, and usually was reported as being an actual court case. For a short history of this document see Papers 3: 120-123; for an extended discussion see Hall (1960).

9 During the 1760s, while in London, Franklin also worked for the Illinois and Indiana land companies.

10 Franklin lived in London from 1757 to 1762 , when he returned to Philadelphia. After losing a close election to the Pennsylvania Assembly in 1764, he returned to London and resumed his position as the Assembly's agent. He added Georgia to his clients in 1767, New Jersey in 1769, and Massachusetts in 1770 . He departed London for Philadelphia on 20 March 1775, four weeks after the first shots of the Revolution were fired at Concord Bridge.

11 In The Canada Pamphlet Franklin refers (1760: 92) to "Machiavel" and "his Prince." In the Observations he addresses himself specifically to the "Prince" only once (1751c: 231), although throughout this essay he maintains his stance as an expert advisor on population to those in power.

12 In 1750 Franklin wrote (p. 440) that migration played a more important role than natural increase in colonial population growth: "This quick Increase is owing not so much to natural Generation, as the Accession of Strangers."

13 Namier presents (1961: 273-282) a treatment of various British perceptions of this issue.

14 Rapid colonial population growth was threatening when contrasted with the slow growth, some said decline (Price, 1780), of the British population. Cassedy discusses (1969: 184-197) the political import that was attached to demographic analyses of Britain and the colonies.

15 This deletion is noted in Papers 9: fnt. 7. p. 58 .
16 Franklin sent this response to The Public Advertiser in December 1773, but apparently it was never published; see Papers 20: 522.

17 The three approaches discussed in the text parallel those identified by Hutchinson (1967: vii): "A theory or idea can be seen in any of several different contexts, each of which adds another dimension to our understanding of the theory and its development. We can look upon a particular contribution as the product of its author, and seek to understand it in relation to the work of which it is a part, the author's total body of writings, and his personal characteristics and life experiences. Or the contribution can be related to its contemporary setting of time and place. And finally, it can be viewed as an element in a stream of continuing intellectual development." Hutchinson chose to follow the last path in his chronicle of population thought.

18 Franklin was attracted to "plain folk with stimulating minds" (Wright, 1986: 217). While in London he met "only a few of the great," and was "rarely entertained at the great houses."

19 Madison's 1791 work, "Population and emigration," bears a striking resemblance to Franklin's work both in form and content. It begins (p. 117): "Both in the vegetable and animal kingdoms every species derives from nature, a reproductive faculty beyond the demand for merely keeping up its stock. . . . Man who preys both on the vegetable and animal species, is himself a prey to neither. He too possesses the reproductive principle far beyond the degree requisite for the bare continuance of his species." Madison's views on emigration mirror those of Franklin. Spengler noted (1935: 701) Franklin's influence on the author of this work while not knowing that Madison wrote it.

20 Madison most clearly expressed this position. In an 1829 piece he forecast (p. 29) a US population of 192 million by 1929 , and noted that by then US density would reach current British levels. This would bring, he feared (pp. 28-30), the rise of a propertyless class that, in a democracy, might be inclined to use government to take from the rich. He thought it necessary to build an institutional bulwark against mob rule. 
21 Franklin contended in a number of places (Wetzel, 1895: 23-24) that manufacturing could be associated with high wages, especially if machinery were used in the pro- duction process, and he determined (1782: 610-612) the types of manufacturing endeavors that might currently be successful in America.

\section{References}

Adams, John. 1811. "Extract from the Boston Patriot, 15 May, 1811," in The Works of John Adams, Vol. 1: 649-664, ed. Charles Francis Adams. Boston: Little, Brown and Company, 1856.

Aldridge, Alfred Owen. 1949. "Franklin as demographer," Journal of Economic History 9, no. 1 (May): 25-44.

1965. Benjamin Franklin: Philosopher and Man. Philadelphia: J. B. Lippincott.

Carey, Lewis J. 1928. Franklin's Economic Views. New York: Doubleday, Doran and Co.

Cassedy, James H. 1969. Demography in Early America: Beginnings of the Statistical Mind, 16001800. Cambridge: Harvard University Press.

Conner, Paul W. 1965. Poor Richard's Politicks: Benjamin Franklin and His New American Order. New York: Oxford University Press.

Detweiler, Robert. 1975. "An observation on the demographic theories of Benjamin Franklin," Population Review 19, nos. 1-2 (January-December): 41-45.

Franklin, Benjamin. 1735. "Reply to a piece of advice," dated 4 March 1735 and published in The Pennsylvania Gazette. Papers 2: 21-26.

1744. Poor Richard, 1744. Papers 2: 393-400.

1745. "Old mistresses apologue" (also called "A letter on marriage" and "Advice to

a young man on the choice of a mistress"), dated 25 June 1745. Papers 3: 27-31.

. 1747. "The speech of Miss Polly Baker," first published 15 April 1747 in the London newspaper, The General Advertiser. Papers 3: 120-125.

1750. Poor Richard Improved, 1750. Papers 3: 437-456.

1751a. "Letter to James Parker," dated 20 March 1751. Papers 4: 117-121.

$175 \mathrm{lb}$. "Felons and rattlesnakes," dated 9 May 1751 and published in The Pennsylvania

Gazette. Papers 4: 130-133.

1751c. Observations Concerning the Increase of Mankind. Papers 4: 225-234.

1753. "Letter to Peter Collinson," undated. Papers 5: 158-160.

1754a. "Three letters to William Shirley," dated 3, 4, and 22 December 1754. Papers

5: 441-447, 449-451.

1754b. A Plan for Settling Two Western Colonies. Papers 5: 456-463.

1755a. "Letter to Richard Jackson," dated 7 October 1755. Papers 6: 216-217.

1755b. "Letter to William Shipley," dated 27 November 1755. Papers 6: 275-277.

1760. The Canada Pamphlet (also known as The Interest of Great Britain Considered, with

Regard to Her Colonies, and the Acquisitions of Canada and Guadaloupe). Papers 9: 47-100.

1764. "Letter to Peter Collinson," dated 30 April 1764. Papers 11: 180-183.

1767. "Letter to Lord Kames," dated 25 February 1767. Papers 14: 62-71.

1768. "Letter to John Alleyne," dated 9 August 1768. Papers 15: 182-185.

1773. "On a proposed act to prevent emigration." Papers 20: 522-528.

1775. "Letter to Joseph Priestley," dated 3 October 1775. Papers 22: 217-218.

1777. "Comparison of Great Britain and America as to Credit, in 1777," about 8

September 1777. Papers 24: 508-514.

1782. "Information to those who would remove to America," believed to have been written in September 1782. The Writings of Benjamin Franklin, Vol. 8: 603-614, ed. Albert Henry Smyth. New York: Macmillan, 1905-06.

. 1784. "Letter to William Strahan," dated 19 August 1784. The Writings of Benjamin Franklin, Vol. 9: 259-264, ed. Albert Henry Smyth. New York: Macmillan, 1905-06. 
1959-90. The Papers of Benjamin Franklin, Vols. 1 to 28, originally ed. Leonard W. Labaree and currently ed. Barbara B. Obreg. New Haven: Yale University Press.

Gibson, James R., Jr. 1989. Americans versus Malthus: The Population Debate in the Early Republic, 1790-1840. New York: Garland Publishing.

Hall, Max. 1960. Benjamin Franklin and Polly Baker: The History of a Literary Deception. Chapel Hill: University of North Carolina Press.

Himes, Norman. 1937. "Benjamin Franklin on population: A re-examination with special reference to the influences of Franklin on Francis Place," Economic History 3, no. 12 (February): 388-398.

Hutchinson, Edward Prince. 1967. The Population Debate: The Development of Conflicting Theories up to 1900. Boston: Houghton Mifflin Co.

Jefferson, Thomas. 1787a. Notes on the State of Virginia, ed. William Peden. Chapel Hill: University of North Carolina Press, 1954.

1787b. "Letter to James Madison," dated 20 December 1787. The Papers of Thomas Jefferson, Vol. 12: 438-442, ed. Julian P. Boyd. Princeton: Princeton University Press, 1955.

Madison, James. 1786. "Letter to Thomas Jefferson," dated 19 June 1786. The Papers of James Madison, Vol. 9: 76-81, ed. Robert A. Rutland and William M. E. Rachal. Chicago: University of Chicago Press, 1975.

. 1791. "Population and emigration," published 19 November 1791 in the National Gazette. The Papers of James Madison, Vol. 14: 117-122, ed. Robert A. Rutland and Thomas A. Mason. Charlottesville: University Press of Virginia, 1983.

1829. "Notes on suffrage." Letters and Other Writings of James Madison, Vol. 4: 21-30. New York: R. Worthington, 1884.

Namier, Lewis. 1961. England in the Age of the American Revolution, 2nd edition. New York: St. Martin's Press.

Price, Richard. 1780. An Essay on the Population of England, from the Revolution to the Present Time, 2nd edition. London: T. Cadell.

Spengler, Joseph John. 1935. "Malthusianism in late eighteenth century America," American Economic Review 25, no. 4 (December): 691-707.

Stourzh, Gerald. 1969. Benjamin Franklin and American Foreign Policy, 2nd edition. Chicago: University of Chicago Press.

Van Doren, Carl. 1938. Benjamin Franklin. New York: Viking.

Wetzel, W. A. 1895. "Benjamin Franklin as an economist," Johns Hopkins University Studies in Historical and Political Science, 13th Series, no. 9.

Wright, Esmond. 1986. Franklin of Philadelphia. Cambridge: Harvard University Press.

Zirkle, Conway. 1957. "Benjamin Franklin, Thomas Malthus and the United States Census," Isis 48, part 1, no. 151 (March): 58-62. 